\title{
Success factors for small rural tourism units: an exploratory study in the Portuguese region of Serra da Estrela
}

\author{
Ana Teodoro ${ }^{1}$, Isabel Dinis ${ }^{2 *}$, Orlando Simões ${ }^{3}$ and Gonçalo Gomes ${ }^{4}$
}

Received: 03/08/2016 Accepted: 03/04/2017

\footnotetext{
${ }^{1}$ Instituto Politécnico de Coimbra, Escola Superior Agrária, Bencanta, 3045-601 Coimbra, Portugal; Tel: +351239802 940, Fax: +315- 239802 979, E-mail: afilteodoro@gmail.com

2 Centro de Estudos em Recursos Naturais, Ambiente e Sociedade (CERNAS); Instituto Politécnico de Coimbra, Escola Superior Agrária, Bencanta, 3045-601 Coimbra, Portugal; Tel: +351- 239802 940, Fax: +315239802 979, E-mail: idinis@esac.pt

3 Centro de Estudos em Recursos Naturais, Ambiente e Sociedade (CERNAS); Instituto Politécnico de Coimbra, Escola Superior Agrária, Bencanta, 3045-601 Coimbra, Portugal; Tel: +351- 239802 940, Fax: +315239802 979, E-mail: orlando@esac.pt

${ }^{4}$ Entidade Regional de Turismo Centro de Portugal, Rua João Mendonça, 8, 3800-200 Aveiro, Portugal; Tel: +351- 234420 760, Fax: +315- 234428 326, E-mail: goncalo.gomes@turismodocentro.pt

* Corresponding author
}

\begin{abstract}
Over the past few decades, tourism has come to be considered a way of promoting economic and social development in peripheral, rural areas where traditional agriculture has declined. This is the case of the Portuguese region of Serra da Estrela, where rural tourism has been seen as a strategy for regional development. However, it is important to understand the extent to which tourism activities are able to meet the expectations of tourists and entrepreneurs, in order to represent a realistic development strategy. The current exploratory study compared the performance of 42 small tourism businesses operating in Serra da Estrela in an attempt to understand the impact of several factors on their success. Using occupancy rate as an indicator of success, a linear model was estimated, revealing the importance of adopting information and communications technologies (ICT) in tourism service as a factor for success. The study also shows that the supply of other services, besides housing, and client satisfaction promote the increase in net occupancy rates. Contrary to expectations, two of the explanatory variables related to management (owning and living in the touristic unit) have a negative impact on success.
\end{abstract}

(C) 2017 Varna University of Management. All rights reserved

Keywords: Rural Tourism, Natural Park, Performance Indicators, Rural Development.

Citation: Teodoro, A., I. Dinis, O. Simões, G. Gomes (2017) Success factors for small rural tourism units: an exploratory study in the Portuguese region of Serra da Estrela. European Journal of Tourism Research 17, pp. 136-148

\section{Introduction}

Serra da Estrela is located in the Central Region (NUT II) of Portugal, being the highest mountain in the country with an altitude of almost 2000 meters at its highest point, the Torre (tower). As pointed out by the European 
Commission (2015), centuries of strong interaction between man and nature have made Serra da Estrela one of the richest areas of the Iberian Peninsula in terms of biodiversity and cultural heritage. An awareness of the uniqueness of the territory is not new. In fact, in 1976, in order to protect the mountain's singularities, the Serra da Estrela Natural Park (ENP) was created. ENP is one of the most extensive protected areas in the country, with about 88,850 ha, which covers territories of the municipalities Celorico da Beira, Covilhã, Gouveia, Guarda, Manteigas and Seia. Currently several national and international conservation statutes protect the region. In this study, for data collection reasons, "Serra da Estrela" is the area defined by the Regional Entity of Tourism of Central Portugal, not exactly matching ENP limits.

Over the past few decades, tourism has been perceived by regional and central policymakers, as well as academics, as a way to promote economic and social development of the region of Serra da Estrela, with emphasis on rural tourism. In the development plan outlining the regional strategy for the period 2014-2020 (CIMBSE, 2014) the relevance of tourism remains. It is stated that, in the region, tourism has an important and even multilevelrole, relating to agriculture, transport and health, as a factor of development and complimentary asset.

At the same time, the lodging capacity in the region has been increasing over the last years, with particular emphasis on rural tourism (RT), in connection with farms and natural resources. Some abandoned farms have been restored and reused for small-scale agro-tourism. Several tourist animation entrepreneurs have been established to help tourists explore the cultural and natural landscape of the region.

Traditionally there has always been a strong seasonality and geographical concentration for tourism with greater demand at weekends and winter holidays focusing on the snow season, at the municipalities closer to Torre, where snow is more abundant (Fernandes and Vieira, 2003). However, a new touristic demand, drawn to culture and nature, especially during the summer, has arisen more recently. In this context, we can expect $\mathrm{RT}$ to remain a potential driver of regional development in the coming years. However, as stated by Wilson et al. (2001) rural tourism development and entrepreneurship cannot work without the direct and indirect participation and collaboration of businesspersons involved in tourism. In particular, rural lodging establishments play a key role in the process (Hernández-Maestro and González-Benito, 2014) but their contribution to development of rural areas depends on their success and resilience.

The purpose of this paper is to contribute to a better understanding of the factors that influence the performance of small rural tourism units, using Serra da Estrela as an exploratory example, so that better and more effective policy measures focusing on RT development can be designed and implemented. Drawing upon the estimation of an empirical model based on a survey conducted in the region, the authors investigate how a set of dependent variables affect the success or performance of RT units.

\section{Literature review}

Success can be defined as the achievement or accomplishment of an aim or objective. According to Kalleberg and Leicht (1991), successful organizations are those that best adapt to fit the opportunities provided and constraints imposed by their environment. In this sense, success is related to performance and competition. For a firm this is the ability to design, produce, and market its products better than others, positively influencing consumers' choice and satisfaction. Tourist satisfaction is ensured when the all operation is customer oriented. That is, when all the organizational culture puts the tourist in the center, acting in order to meet their needs (Deshpandé et al., 1993; Jaworski et al., 2000; Steinman et al., 2000; Polo-Peña et al., 2013). Customer orientation is seen as a competitive advantage in the market, particularly in RT (Slater and Narver, 1994, Otto and Brent-Ritchie, 1996; Haber and Lerner, 1999; Reichel and Haber, 2005; De Nisco et al., 2015). As pointed out by Ali et al. (2014) memorable touristic experiences can develop lasting and positive memories for consumers, which can ultimately influence their loyalty behaviours. However, in 
the RT industry, the issue of success is not only about business. The literature shows that RT entrepreneurship motivations are often linked with non-economic personal goals, and therefore, the desired outcomes may not be primarily financial. International studies, such as Morrison and King (2002) and Polo-Peña et al. (2013) argue that sometimes firms continue to operate in the RT market, despite achieving only minimal financial return, because owners associate their business with a certain lifestyle and to the possibility of family assets recovery. Several studies show that success in RT, from the owner's point of view, is also measured by the satisfaction of being appreciated and valued by others, not only customers or tourists but also by the local people who value the preservation and the promotion of local heritage (Cavaco, 2000). Equally important, the pleasure to receive, entertain and interact with people from different cultures is also recognized as a reason for RT entrepreneur's fulfilment (Morrison and King, 2002; Simpson, 2008).

From this perspective, Polo-Peña et al. (2012) suggest three types of results (financial results, "personal" results for the entrepreneur, and results to the "destination", i.e. to the local development of rural areas), combining an analysis of tangible and intangible factors. The use of subjective performance measures together with objective indicators had already been advocated in a study about the travel industry by Fick and Brent-Ritchie (1991), since many factors that contribute to the tourist experience cannot be objectively measured.

In fact, a wide range of internal and external factors can influence success in rural lodging establishments, involving a combination of inherited or created assets (e.g., natural resources and infrastructure) and processes. Regarding external assets, as pointed out by Tsai et al. (2009), the tourism industry benefits from a destination's economic growth and stability and community developments that help to create demand for hotel rooms. In the same line Haber and Reichel (2007) argue that location is one of the main factors that contribute to the success of touristic businesses because it is related to several physical and social features that significantly influence the tourist experience. The environmental factor, as Lerner and Haber (2000) call it, has a direct impact on the chances of success and survival in case of tourist ventures. For example, the specific materials and practices used in regional architecture, as well as landscape, local culture and traditions may become important issues. The same happens with the provision of regional infrastructures and services, such as basic infrastructure (water, electricity, roads) or shopping, entertainment and cultural facilities (Fridgen, 1984; Leaper, 1990; Andersen 1996; Lerner and Haber, 2000).

Internal assets also play a crucial role in success. As stated before, to have success, RT units must focus on customer satisfaction. To ensure customer satisfaction, it is necessary to provide a quality service at all levels (reception, facilities, breakfast, touristic-animation). Several authors such as Schneider and Bowen (1995) and Lerner and Haber (2000) found that the provision of a bundle of services, rather than a basic lodging service, improves success because rural tourists tend to look for recreational activities while staying in rural areas. Also important in a tourist-oriented process are the options given to tourists to make their reservation or purchase the service. Since the average size of RT units often limits resource availability, information and communication technologies (ICT) offer a major advantage in building competitiveness because technology is affordable and suitable for small businesses (McCartan-Quinn and Carson, 2003; Buhalis and Law, 2008).

Several authors have studied the impact of ICT on RT business performance at different phases of the tourist experience: pre-visit, visit and post-visit. As Polo-Peña et al. (2013) sum up, pre-visit is when tourists form a prior perceived image about the destination and make their reservation. At this stage, tourists may use organization's web sites and social media networking to get information about places to visit or stay and booking. With regard to pre-visit, recent research has showed that online visibility enhances RT business performance (Nieto et al., 2011; Melo et al., 2017). Visit is the stay period during which ICT is relevant for check-in and departure 
management and internet and social media access and use. Finally, post-visit activities refer to the firm's follow-up in relation to the clients they have served. ICT is then useful to manage clients' forums and promote special events. Particularly, the comments left by clients in the social networks or reservation centers reveal their degree of satisfaction and suggest required improvements. In this regard, several studies (Ye et al., 2009, Ye et al., 2011; Sparks and Browning, 2011; Yacouel and Fleischer, 2012; Nieto et al., 2014; Phillips et al., 2015) indicate that the number and quality of reviews provided online by consumers determine RT business performance. This means the existence of a feedback effect that leads to increasing or decreasing demand according to previous reviews.

Polo-Peña et al. (2013), using Structural Equation Modeling, investigated the impact of the use of ICT in RT performance perception at the three different phases, finding that combined ICT use and customer orientation adoption contribute to better outcomes for RT activity. They also remark that ICT use per se does not universally guarantee that business performance will benefit. To do so, they must be used in a consumer-oriented context.

Regarding processes, RT units have some particularities that are worthy emphasizing. RT ventures are often described as small household units, allowing a closer interaction between supplier and customer (Getzs and Carlsen, 2000; Reichel and Haber, 2005). That leads to a greater involvement of tourists in the "rural experience", helping to increase customer satisfaction (Kastenholz and Sparrer 2009; Cunha et al., 2011). Processes depend mostly on the psychological traits, skills, motivations and choices made by the business leaders, particularly in RT units where the entrepreneur often performs all the tasks needed for the functioning of the housing, becoming himself one of the most important success factors. Campón-Cerro (2015) highlights the importance of relationships in RT destinations as a key element for getting customer's loyalty and enhancing profitability in the long run. Certain behavioral skills such as hospitality and good communication abilities are identified as drivers of good performance in small tourist resorts (Olsen et al., 1992; Haber and Reichel, 2007). Age, gender, education and good skills in financial management, accounting and marketing are characteristics that may determine managerial behaviour and leadership style which indirectly have an effect on business performance (Cooper et al., 1994; Robinson and Sexton, 1994; Lerner and Haber, 2000; Minett et al., 2009).

As previously discussed, the concepts of success and performance are not well established, comprising a certain level of subjectivity. From the owner's point of view it may be related to financial results but also to the achievement of other expectations regarding for example the preservation of family assets. Furthermore, there is a multiplicity of issues that can interfere with the functioning and performance of RT units. Accordingly, the present study used a multidimensional approach in order to understand RT success and identify these critical factors.

\section{Methods \\ Data collection}

The analysis was mainly based on a survey of RT managers held between October 2014 and March 2015 using a fully structured questionnaire. With few exceptions, the survey was administered online after a personal or phone contact, in order to inform potential participants about the research and the objectives of the survey. From the 150 RT lodgment units recorded in the Serra da Estrela region, only 42 managers accepted to participate in this study.

The questionnaire focused on eight groups of questions, starting with the description of the lodgment, including identification, history and operational structure. The purpose of the second set of questions was to identify the methods of booking made available to customers. The goal of the third group of questions was to understand the methods deployed by managers to communicate their services. The fourth group of questions focused on complementary services, such as recreational and leisure activities, contact with local agriculture and accessibility to traditional products. The fifth group of questions was about attributes managers thought were more 
appreciated and valued by their customers. The sixth set of questions gathered information about the manager, namely gender, age, educational background, training and experience in tourism. In the seventh group, managers were questioned on the amount of money spent to adapt their house to RT, as well as about funding sources. Finally, the last set of questions was divided between the motivations and expectations of managers seeking to understand the reasons why they invested, their satisfaction with the results and how they perceive the future of their business.

In addition to the questionnaire, managers also filled in a form on a monthly basis with information on the number of guests, overnight stays and number of available and unavailable beds. In the meantime, other information was directly collected from the internet, regarding online facilities. For this purpose, the web pages of the RT units were visited, in order to check the use of ICT in advertising (housing and others) and booking. When available, the rankings given by guests and released on internet reservation sites were also registered.

\section{Variables and model}

To begin with, it was necessary to find a dependent variable that could behave as a proxy for performance or success of RT units. In the literature of hotel performance, results are usually measured by using both financial and operating measures (Gray et al., 2000; Reichel and Haber, 2005; Sainaghi, 2010; Pnevmatikoudi and Stavrinoudis, 2016). However, reliable financial indicators are not easily obtained in surveys. Moreover, as mentioned by Sainaghi and Baggio (2014), financial indicators are often influenced by managerial and accounting adjustments. On the other hand, operating indices are usually built around occupancy (Damonte et al., 1997; Reichel and Haber, 2005; Akbaba, 2012; Sainaghi and Baggio, 2014), price (Danziger et al., 2006), or combined in the revenue per available room (REVpar) (Fleischer and Tchetchik, 2005; Namasivayam et al., 2007; Kim et al., 2015). According to Cohen and Olsen (2013), market performance is the degree to which a hospitality firm outperforms its competitors in attracting new customers, increasing occupancy rates.

Table 1. Variables description

\begin{tabular}{|c|c|}
\hline Variable & Description \\
\hline \multicolumn{2}{|c|}{ Dependent variable } \\
\hline NOR & Net Occupancy Rate \\
\hline \multicolumn{2}{|c|}{ Explanatory Variables } \\
\hline \multicolumn{2}{|c|}{ 1) RT units characteristics/Internal and External Assets } \\
\hline year & Start-up year \\
\hline nworkers & Number of hired workers \\
\hline services & Supply of other services than lodging; equals 1 if yes and 0 otherwise. \\
\hline regprod & Accessibility to regional products; equals 1 if yes and 0 otherwise. \\
\hline sitebook & Booking on the website; equals 1 if available and 0 otherwise. \\
\hline naturalpark & Location in the natural park; equals 1 if yes and 0 otherwise. \\
\hline \multicolumn{2}{|c|}{ 2) Manager characteristics/Processes } \\
\hline gender & Equals 1 if male and 0 if female. \\
\hline age & Age of the manager, measured in years \\
\hline experience & Training/experience in tourism or management, equals 1 if any and 0 otherwise. \\
\hline residence & Equals 1 if the manager lives in the RT unit and 0 otherwise. \\
\hline owner & Equals 1 if the manager is the property owner and 0 otherwise. \\
\hline \multicolumn{2}{|c|}{ 3) Rating - categorical variable with 3 levels } \\
\hline rating0 & Equals 1 if the RT unit is not rated in internet reservation sites and 0 otherwise \\
\hline rating1 & Equals 1 if the RT unit has a rate smaller than the threshold and 0 otherwise \\
\hline rating2 & Equals 1 if the RT unit has a rate not smaller than threshold and 0 otherwise \\
\hline
\end{tabular}


In this study, it was decided to look at success from this latest perspective using net occupancy rate as the dependent variable. Since price variations between RT units located in the Serra da Estrela region are small, the use of REVpar showed no advantages. Net occupancy rate was obtained by dividing the total number of overnight stays by the total number of available bed places, during the reference period (i.e. the sum of bed places available per day, excluding extra beds and net of seasonal closures and other temporary closures for decoration, by police order, etc.).

Three groups of explanatory variables (Table 1) were included in the model, chosen according to the main determinants of RT units performance described in section 2 .

The first group contains six variables related to the RT unit's features: lodgement age, measured by the start-up year; size, measured by the number of employees; supply of services other than lodging; accessibility to regional products and website booking.

As mentioned in section 2, external assets may determine the success of tourism units. In this case, RT units are located in a relatively small area, with no major differences regarding regional infrastructures and services. However, since nature-based tourism has become increasingly important in the area, it seemed relevant to include a variable related to the distance to natural attractions. The variable naturalpark distinguishes lodgements located inside the natural park from the others.

The second group includes five manager characteristics: gender; age; training or professional experience in tourism or management; ownership (whether the manager is or is not the house owner); and manager residence (whether he lives or does not live in the RT unit). Finally, customer's ratings posted on internet reservation sites were also included as an explanatory variable. The rating level allows one to measure the degree of tourist satisfaction and to test to what extent that degree affects the demand of others.

Rating is a categorical variable that distinguishes RT units not rated on internet reservation sites (rating $0=1$ ) from those that, being rated, achieve ratings under or above 8.4 (rating1=1 and rating2=1, respectively). This threshold is the average of the rating interval of all Serra da Estrela TR units classified in the site http://www.booking.com.

Before choosing Booking.com other e-rating tools had been considered, but it was concluded that Booking would be the most efficient and objective because it is the one most commonly used by Serra da Estrela RT units. Even those that use other lodging reservations website engines also use Booking.com. As one of the peer reviewers kindly noted, Booking.com is a travel agent and therefore members actually benefit not only from ICT, but from third party/tourist intermediaries. However, the type of information shared and the features provided are the same for all members (identification and location of houses, facilities available to tourists, images). Using only data from Booking.com allowed to isolate the "intermediary effect" and to ignore the impact that this intermediary has by itself, on the occupation rates.

Thereby, the performance of a RT unit, measured by the net occupancy rate (NOR) between October 2014 and March 2015, was specified as follows:

$N O R=\alpha+\sum_{n=1}^{6} \beta_{n}$ Unit $_{n}+\sum_{r=1}^{5} \gamma_{r}$ Manager $r+\lambda$ Rating $+e_{i j}$

The variables included in Unit, Manager ana Rating refer, respectively, to the first, second and third groups of variables earlier described.

The main descriptive statistics regarding all the variables used in the model are displayed in Table 2. These statistics show that occupancy rates are low in RT units in the Serra da Estrela Region, varying between 0 and $43 \%$, with a mean of $12.7 \%$. The units are small, with no more than 12 hired workers with an average of 2.5. Most units offer services other than lodging and provide contact with regional products. Less than a third have an institutional website with marketing and booking purposes. About half are located inside the natural park. 
Regarding managers, there is a predominance of male individuals. The average age of managers is 54 and most of them have no training or experience in tourism or management. Managers are mainly the owners of the houses but do not live in the RT unit. A little more than a third of the housings are rated in internet reservation sites, with high rankings.

\section{Estimation and Results}

The model presented in the previous section was estimated using Ordinary Least Squares
(OLS). Due to missing values in the dependent variable, the number of observations was limited to 37 . In Table 3, we present the estimation results. The estimated coefficients represent the marginal effects of the independent variables $(d y / d x)$ on the dependent variable. For dummy variables, $\mathrm{dy} / \mathrm{dx}$ represents the change in the dependent variable as a result of the discrete change from 0 to 1 in the explanatory variable. The statistical and econometric analysis was performed using STATA12 $\circledR$.

Table 2. Descriptive statistics

\begin{tabular}{lrrrrr}
\hline Variable & Observations & \multicolumn{1}{c}{ Mean $^{*}$} & Std Dev $^{*}$ & \multicolumn{1}{c}{ Min } & \multicolumn{1}{c}{ Max } \\
\hline NOR & 37 & 12.7 & 11.2 & 0 & 43 \\
\hline Year & 42 & 2005 & 8.7 & 1976 & 2015 \\
nworkers & 42 & 2.5 & 0.46 & 0 & 12 \\
Services & 42 & 0.595 & & & \\
Regprod & 42 & 0.738 & & & \\
Sitebook & 42 & 0.286 & & & \\
naturalpark & 42 & 0.476 & & & \\
\hline Gender & 42 & 0.643 & & & \\
Age & 42 & 54 & 11.46 & & \\
experience & 42 & 0.333 & & & \\
residence & 42 & 0.333 & & & \\
Owner & 42 & 0.905 & & & \\
\hline rating0 & 42 & 0.357 & & & \\
rating1 & 42 & 0.167 & & & \\
rating2 & 42 & 0.476 & & & \\
\hline
\end{tabular}

$\left(^{*}\right)$ For binary variables the mean corresponds to relative frequency; standard deviations are omitted.

Table 3. Estimation Results

\begin{tabular}{lrrrr}
\hline Variable & Coefficient & Std. Err. & \multicolumn{1}{c}{$\mathrm{t}$} & $\mathrm{P}>|\mathrm{t}|$ \\
\hline year $^{* *}$ & -0.78233 & 0.31340 & -2.50 & 0.020 \\
nworkers $^{*}$ & -1.40596 & 0.69031 & -2.04 & 0.053 \\
services & 3.65245 & 3.32407 & 1.10 & 0.283 \\
regprod & 1.21232 & 3.42976 & 0.35 & 0.727 \\
sitebook & 11.95535 & 3.23219 & 3.70 & 0.001 \\
naturalpark & -1.18348 & 3.58197 & -0.33 & 0.744 \\
\hline gender & -0.64301 & 3.63143 & -0.18 & 0.861 \\
age $^{* *}$ & -0.27932 & 0.11139 & -2.51 & 0.020 \\
experience $^{* *}$ & -2.73356 & 3.32591 & -0.82 & 0.420 \\
residence $^{* * *}$ & -10.39118 & 3.43350 & -3.03 & 0.006 \\
owner $^{* * *}$ & -9.19935 & 3.23677 & -2.84 & 0.009 \\
\hline rating1 & -9.04944 & 4.36456 & -2.07 & 0.005 \\
rating2 & 4.11361 & 4.21238 & 0.98 & 0.339 \\
\hline constant & 1606.904 & 633.712 & 2.54 & 0.018
\end{tabular}

Number of obs $=37 \mathrm{~F}(13,23)=8.53$ Prob $>F=0.0000$ R-squared $=0.5999$ Root MSE $=8.8741$

${ }^{* \star *}$ Statistically significant at $p$-value $<0.01 ;{ }^{* *}$ Statistically significant at $p$-value $<0.05$; Statistically significant at $p$-value $<0.1$. 
From the estimation results, we can observe that the dependent variables with significant effect on occupancy rates were year, nworkers, sitebook, age, residence, owner and rating1. According to the results, age positively and significantly influences occupation rates, meaning that, holding other things constant, consumers prefer older TR units. For each additional year in the RT market, the net occupation rate increased 0.8 percentage points. These findings are in line with previous research (Van de Ven et al., 1984) that regards survival of small firms as a main success indicator and can be related to the fact that it is not easy for new entrants to get the competitive advantages that older RT units may have created and defended. Probably, previous entrants are better established in the market and already have some loyal clients that often return.

The number of workers showed a negative effect on occupancy rates. Since the number of workers was chosen as a size variable, this result surprisingly suggests that larger units had more difficulty to ensure high occupancy rates. In fact, size is identified in many studies as a determinant of success for hotels (Barros, 2004; Chen and Tseng, 2005) and RT units (Fleischer and Tchetchik, 2005), given the positive relationship between dimension and economies of scale. In the Region of Murcia, Albaladejo-Pina and Díaz-Delfa (2009) also found that size (measured by the number of rooms) enhance a rural house's attractiveness for the rural tourist. Exceptions can be found in Anastassopoulos et al. (2009) and Sainaghi (2011). The explanation for this apparent contradiction may lie in the fact that rural tourists seek a greater involvement in the "rural experience"(Kastenholz and Sparrer, 2009) that smaller units can more easily provide.

It is well recognized that a manager's age influences leadership styles, behaviours and competencies. The study by Tavitiyaman et al. (2014) shows that younger managers emphasize some issues that are critical in RT such as the top leadership competency priorities, namely concern for the community and communication skills. Moreover, it has also been argued that younger business owners are more active and energetic and have more passion and motivation for their businesses as they have larger career aspirations (Kangasharju, 2000). In line with expectations, the present study shows that units managed by younger managers have higher occupancy rates. Other things held constant, an additional year in manager age leads to a 0.3 percentage point decrease in net occupation rate. Contrary to age, manager gender showed no statistical significance in explaining RT unit performance. Ownership and residence also stand as significant issues, although with an opposite effect to what was initially expected. In fact, ownership and manager attendance should contribute to a more tourist-oriented management, improving customer satisfaction and therefore success. However, the present study indicates that when the manager is simultaneously the RT owner, the net occupancy rate decreases about 9 percentage points. Regarding residence, the results show that net occupancy rates tend to be 10 percentage points higher when the manager does not live in the RT unit. To explain these unexpected results Polo-Peña et al. (2012) insight can be helpful. These authors believe that the managers of small RT projects may be more focused on efficiently managing their resources rather than developing strategic market plans. In the Serra da Estrela region this appears to be the case since family heritage preservation was one of the main reasons cited by the participants in the study to justify their financial investment in RT.

The significance of the variables sitebook and rating endorses the relevant role of ICT in previsit and post-visit stages. In fact, the results clearly show that online booking positively contributes to RT units' performance. Everything else remaining constant, the net occupancy rate in RT units having internet sites with a booking option increases 12 percentage points when compared to others. This is an expected outcome since the use of ICT is seen as a strategic success factor of small business by several authors (Sigala, 2004; Chathoth \& Law, 2011; Nieto et al., 2011; Polo-Peña et al., 2013; Melo et al., 2017). Particularly, when used at the pre-visit stage, ICT increases visibility and simplifies booking procedures, enhancing RT performance. 
Regarding post-visit, the significant impact of online ratings is in line with the findings by Nieto et al. (2014) and Phillips et al. (2015), although in the present study what really stood out was the negative effect of low ratings when compared with the absence of ratings. In the model, the coefficients of the variables rating 1 and rating 2 show, respectively, the impact of good and not so good reviews in net occupancy rate, when compared to the absence of internet rating.

The model suggests that, when compared with an RT with no internet rating, an RT with an average rating below 8.4 may expect 9 percentage points decrease in its occupancy rate. It also shows that higher rates can have a positive impact on occupancy but this result is not statistically significant, probably due to small sample size.

\section{Regarding education and professional experience, several authors such as Tavitiyaman et al. (2014) and Haber and Reichel (2007) point out that those features can help managers to better analyse the business situations and apply leadership skills to numerous situations and that lack of education limits decision-making and compromises small tourism business performance.}

Contrary to expectations, education and prior entrepreneurial experience showed negative, though not significant, association with occupancy rates in Serra da Estrela RT units. This might suggest, as pointed out in other studies with similar results (Lerner and Haber, 2000; Haber and Reichel, 2007), that in the tourism industry previous knowledge or specialized education per se do not assure success. Besides, as the authors claim, entry barriers in tourism are not as high as in other industries, where previous managerial experience and a higher level of education are required, reducing the relevance of these factors.

It is also noteworthy that, contrary to expectations, location within the natural park area has a negative influence, though not significant, in the occupancy rate. This result is probably related to worse accessibility to RT units located inside the park and to the greater amount of time needed by tourists to reach some basic services such as food and health care.

\section{Conclusion}

This article investigated the relationship between both RT units and manager profiles and firm performance. The findings of this study can be useful to RT entrepreneurs as a tool for developing marketing and advertising strategies since it increases awareness of the management and housing attributes that impact successful occupancy rates.

The first important conclusion that can be drawn is that ICT may significantly influence RT unit performance. In fact, having a formal website appears to be the most powerful determinant of RT unit performance, positively and significantly influencing occupancy. When considering the post-visit point of view, adoption of ICT can also influence the outcomes of RT activity. In particular, bad online ratings have a strong negative and statistically significant effect on occupancy rates. Therefore, rural lodging establishment owners must be encouraged to develop formal websites and to monitor the presence of low ratings and negative comments in online reviews. Thus, managers will be able to respond to negative opinions and clarify possible misunderstandings. At the same time, they may take advantage of those reviews by solving the identified problems and communicating progress or resolution.

This study also shows that Serra da Estrela rural tourists prefer small lodging units longer established in the market. Another conclusion may be that the main goal of RT entrepreneurs is heritage preservation rather than competitiveness, since ownership and on-site residence negatively influences market performance. These findings may help to explain the low contribution of RT to the region's real development, particularly with regard to job creation, and may have important regional development policy implications. However, these results require confirmation from future studies, more comprehensive in both time and study area.

The focus of this research was very local, having a low number of participants and a 
narrow registration period of occupancy rates. Therefore, it was not possible to generalize our findings or to verify their efficacy in other locations. Broader studies of this type in other rural areas would help to confirm, modify and refine the findings in this paper through comparison. Moreover, future research should also incorporate other market performance indicators (e.g. financial performance; customer loyalty and satisfaction; owners, managers, and employees satisfaction; rural population approval) to fully capture the factors of success.

\section{References}

Akbaba, A. (2012) Business performance of small tourism enterprises: a comparison among three sub-sectors of the industry. Anatolia: An International Journal of Tourism and Hospitality Research, 23 (2), 177-195

Albaladejo-Pina, I. P. and Díaz-Delfa, M. T. (2009) Tourist preferences for rural house stays: Evidence from discrete choice modelling in Spain. Tourism Management, 30(6), 805-811.

Ali, F., Hussain, K., Ragavan, A. (2014) Memorable customer experience: examining the effects of customers experience on memories and loyalty in Malaysian resort hotels. Procedia - Social and Behavioral Sciences, 144, 273-279.

Anastassopoulos, G., Filippaios, G. and Phillips, P. (2009). An eclectic investigation of tourism multinationals: evidence from Greece. International Journal of Hospitality, 28 (2), 185-194.

Andersen, A. (1996). Yield Management in Small and Medium-Sized Enterprises in the Tourist Industry. Brussels: European Commission, Directorate General 23Tourism Unit.

Barros, C.P. (2004) A stochastic cost frontier in the Portuguese hotel industry. Tourism Economics, 10 (2), 177-192.

Buhalis, D. and Law, R. (2008) Progress in information technology and tourism management: 20 years on and 10 years after the Internet - The state of eTourism research. Tourism Management, 29, 609623.

Campón-Cerro, A. M. (2015) Loyalty to rural tourism destinations: a causal study of determinants using a transactional and relational marketing approach. Doctoral Dissertation Summary. European Journal of Tourism Research, 11, 154-157.

Cavaco, C. (2000) Turismo, comércio e desenvolvimento rural. In Almeida, A. and Riedl, M. (org.) (2000) Turismo rural: Ecologia, lazer e desenvolvimento. Bauru: EDUCS, 69-94.

Chen, H.M., Tseng, C.H. (2005). The performance of marketing alliances between the tourism industry and credit card issuing banks in Taiwan. Tourism Management 26 (1), $15-24$.

Chathoth, P. K. and Law R. (2011) Managerial perceptions of information technology and their impact from a transaction cost perspective. Journal of Travel \& Tourism Marketing, 28(8), 787-803.

CIMBSE (2014) Plano Estratégico de Desenvolvimento Intermunicipal: Beiras e Serra da Estrela 2020. Comunidade Intermunicipal das Beiras e Serra da Estrela. URL: http://www.cmalmeida.pt/municipio/noticiasdomunicipio/Do cuments/Plano\%20estrat\%C3\%A9gico\%20 CIM-BSE.pdf (Accessed on 16.01.2016)

Cohen, J. F. and Olsen, K. (2013) The impacts of complementary information technology resources on the service-profit chain and competitive performance of South African hospitality firms. International Journal of Hospitality Management, 34(1), 245-254.

Cooper, A.C., Gimeno-Gascon, F.J. and Woo, C.Y. (1994) Initial human and financial capital as predictors of new venture performance. Journal of Business Venturing 9, 371-395.

Cunha, C., Kastetenholz, E. and Carneiro, M.J. (2011) Análise da relevância do empreendedorismo estilo de vida para o desenvolvimento na oferta de turismo em espaço rural. In Figueiredo, E. (coord.) (2011) Rural Plural, olhar o presente, imaginar o futuro. Castro Verde: 100Luz, 203-214.

Damonte, L. T., Rompf, P. D., Bahl, R. and Domke, D. J. (1997) Brand affiliation and property size effects on measures of performance in lodging properties. Hospitality Research Journal, 20(3), 1-16.

Danziger, S., Israeli, A. and Bekerman, M. (2006). The relative role of strategic assets 
in determining customer perceptions of hotel room price. International Journal of Hospitality Management, 25 (1), 129-145.

De Nisco, A., Riviezzo, A. and Napolitano, M.R. (2015) An Importance-Performance analysis of tourist satisfaction at destination level: evidence from Campania (Italy). European Journal of Tourism Research, 10, 64-75

Deshpandé, R., Farley, J. U. and Webster, F. E., Jr. (1993). Corporate culture, customer orientation, and innovativeness in Japanese firms: A quardard analysis. Journal of Marketing, 57(1), 23-38.

European Commission (2015) Getting cultural heritage to work for Europe: Report of the Horizon 2020 Expert Group on Cultural Heritage. Luxembourg: Publications Office of the European Union.

Fernandes, G. and Vieira, A. (2003) Problemáticas do turismo em áreas naturais e o seu significado nos concelhos do Parque Natural da Serra da Estrela. In Simões, O. and Cristovão, A. (org.) (2003) TERN Turismo em Espaços Rurais e Naturais. Coimbra: Edições IPC- Inovar para Crescer, 135-152.

Fick, G. R. and Brent-Ritchie, B. J. R. (1991) Measuring service quality in the travel and tourism industry. Journal of Travel Research, 30(2), 2-9.

Fleischer, A. and Tchetchik, A. (2005) Does rural tourism benefit from agriculture? Tourism Management, 26(4), 493-501.

Fridgen, J.D. (1984) Environmental psychology and tourism. Annals of Tourism Research, 11, 19-39

Getz, D. and Carlsen, J. (2000) Characteristics and goals of family and owner-operated businesses in the rural tourism and hospitality sectors. Tourism Management, 21, 547-560.

Gray, B.J., Matear, S.M. and Matheson, P.K. (2000) Improving the performance of hospitality firms. International Journal of Contemporary Hospitality Management, 12 (3), 149-155.

Haber, S. and Lerner, M. (1999) Correlates of tourist satisfaction. Annals of Tourism Research 26, 197-201.

Haber, S. and Reichel, A. (2007). The cumulative nature of the entrepreneurial process: The contribution of human capital, planning and environment resources to small venture performance. Journal of Business Venturing, 22, 119 - 145.

Hernández-Maestro, R. and González-Benito, O. (2014). Rural lodging establishments as drivers of rural development. Journal of Travel Research, 53, 83-95.

IESE (2008) Estudo de Caracterização do Turismo no Espaço Rural e do Turismo de Natureza em Portugal, versão resumida. Direção Geral de Agricultura e DesenvoIvimento Rural. URL: http://www.dueceira. pt/docs/ publicacoes/99_estudo\%20TER.pdf (Accessed on 16.01.2016).

Jaworski, B., Kohli, A. and Sahay, A. (2000) Market-driven versus driving market. Journal of the Academy of Marketing Science, 28(1), 45-54.

Kalleberg, L. and Leicht, K. (1991) Gender and Organizational Performance: Determinants of Small Business Survival and Success. Academy Management Journal, 34 (1), 136161.

Kangasharju, A. (2000) Growth of the smallest: determinants of small firm growth during strong macroeconomic fluctuations. International Small Business Journal, 19(1), 28-43.

Kastenholz, E. and Sparrer, M. (2009) Rural Dimensions of the Commercial Home. In Lynch, Maclntosh and Tucke (eds.) Commercial Homes in Tourism: An international perspective, London: Routledge, 138-149.

Kim, W. G., Lim, H. and Brymer, R. A. (2015). The effectiveness of managing social media on hotel performance. International Journal of Hospitality Management, 44, 165-171.

Leaper, N. (1990) Tourist attraction systems. Annals of Tourism Research, 17, 367-384.

Lerner, M. and Haber, S. (2000) Performance factors of small tourism ventures: The interface of tourism, entrepreneurship and the environment, Journal of Business Venturing, 16, 77-100.

McCartan-Quinn, D. and Carson, D. (2003) Issues which impact upon marketing in the small firm. Small Business Economics, 21, 201-213.

Melo, A., Hernandez-Maestro, R. and MunozGallego, P. A. (2017). Service Quality Perceptions, Online Visibility, and Business Performance in Rural Lodging Establishments. Journal of Travel Research, 56(2), 250-262. 
Minett, D., Yaman, H.R. and Denizci, B. (2009) Leadership styles and ethical decision making in hospitality management. International Journal of Hospitality Management, 28 (4), 486-493.

Morrison, A. J. and King, B. E. M. (2002) Small tourism businesses and e-commerce: Victorian tourism online. Tourism and Hospitality Research, 4, 104-116.

Namasivayam, K., Miao, L. and Zhao, X. (2007) An investigation of the relationships between compensation practices and firm performance in the US hotel industry. International Journal of Hospitality Management, 26 (3), 574-587.

Nieto, J., Hernández-Maestro, R. M. and Muñoz-Gallego, P. A. (2011) The Influence of Entrepreneurial Talent Establishments in Spain. International Journal of Tourism Research, 13(1), 17-31.

Nieto, J., Hernández-Maestro, R. M. and Muñoz-Gallego, P. A. (2014) Marketing decisions, customer reviews, and business performance: The use of the Toprural website by Spanish rural lodging establishments. Tourism Management, 45, 115-123.

Olsen, M.D., West, J.J. and Tse, E.C. (1992) Strategic Management in the Hospitality Industry. New York: Van Nostrand Reinhold.

Otto, J. E. and Brent-Ritchie, B. J. R. (1996) The service experience in tourism. Tourism Management, 17(3), 165-174.

Phillips, P., Zigan, K., Santos Silva, M. M., and Schegg, R. (2015) The interactive effects of online reviews on the determinants of Swiss hotel performance: A neural network analysis. Tourism Management, 50, 130141.

Pnevmatikoudi, K. and Stavrinoudis, T. (2016) Classification of hotel performance measurement indicators presented in international scientific research. European Journal of Tourism Research, 12, 82-98.

Polo-Peña, A. I., Frías-Jamilena, D. M. and Rodríguez-Molina, M. Á. (2012) Marketing practices in the Spanish rural tourism sector and their contribution to business outcomes. Entrepreneurship \& Regional Development, $24(7-8), 503-521$.

Polo-Peña, A. I., Frías-Jamila, D.M and Rodríguez-Molina, M. Á. (2013) Impact of Customer Orientation and ICT Use on the
Perceived Performance of Rural Tourism Enterprises. Journal of Travel \& Tourism Marketing, 30 (3), 272-289.

Reichel, A., Haber, S. (2005) A three-sector comparison of the business performance of small tourism enterprises: an exploratory study. Tourism Management 26, 681-690.

Robinson P.B. and Sexton, E.A. (1994) The effect of education and experience on selfemployment success. Journal of Business Venturing, 9,141-156.

Sainaghi, R. (2010) Hotel performance: state of the art. International Journal of Contemporary Hospitality Management, 22 (7), 920-952.

Sainaghi, R. (2011) RevPAR determinants of individual hotels: evidences from Milan. International Journal of Contemporary Hospitality Management, 23 (3), 297-311.

Sainaghi, R. and Baggio, R. (2014) Structural social capital and hotel performance: Is there a link? International Journal of Hospitality Management, 37, 99-110.

Schneider, B. and Bowen, E.D. (1995) Winning the Service Game. Boston: Harvard Business School Press.

Sigala, M. (2004) Integrating and Exploiting Information and Communication Technologies (ICT) in restaurants operations. Journal of Foodservice Business Research, 6(3), 55-76.

Simpson, M. C. (2008) Community benefit tourism initiatives-A conceptual oxymoron? Tourism Management, 29, 1-18.

Slater, S. F. and Narver, J. C. (1994) Market orientation, customer value, and superior performance. Business Horizons, 37(2), 22 28.

Sparks, B. A. and Browning, V. (2011) The impact of online reviews on hotel booking intentions and perception of trust. Tourism Management, 32(6), 1310 -1323.

Steinman, C., Deshpandé, R. and Farley, J. U. (2000) Beyond market orientation: When customers and sup-pliers disagree. Journal of the Academy Marketing Science, 28(1), 109-119.

Tavitiyaman, P., Weerakit, N., and Ryan, B. (2014) Leadership Competencies for Hotel General Managers: The Differences in Age, Education, and Hotel Characteristics. International Journal of Hospitality \& Tourism Administration, 15(2), 191-216. 
Tsai, H., Song, H., and Wong, K. (2009) Tourism and Hotel Competitiveness Research. Journal of Travel \& Tourism Marketing, 26(5-6), 522-546.

Van de Ven, A., Hudson, R. and Schroeder, D. (1984) Designing new business start-up: Entrepreneurial, organizational and ecological considerations. Journal of Management, 10(1), 87-107.

Vieira, C. and Figueiredo, E. (2011) "Juntar a Fome à Vontade de Comer", Ligação entre o turismo rural e os produtos agroalimentares na Serra da Estrela. In Figueiredo, E. (coord.) (2011) Rural Plural, olhar o presente, imaginar o futuro. Castro Verde: 100Luz, 105-120.
Wilson, S.; Fesenmaier, D.; Fesenmaier, J. and Van Es, J. (2001) Factors for Success in Rural Tourism Development. Journal of Travel Research, 40, 132-138.

Yacouel, N. and Fleischer, A. (2012) The role of cybermediaries in reputation building and price premiums in the online hotel market. Journal of Travel Research, 51(2), 219-226.

Ye, Q., Law, R. and Gu, B. (2009) The impact of online user reviews on hotel room sales. International Journal of Hospitality Management, 28(1), 180-182.

Ye, Q., Law, R., Gu, B and Chen, W. (2011) The influence of user-generated content on traveler behavior: an empirical investigation on the effects of e-word-ofmouth to hotel online bookings. Computers in Human Behavior, 27, 634639. 